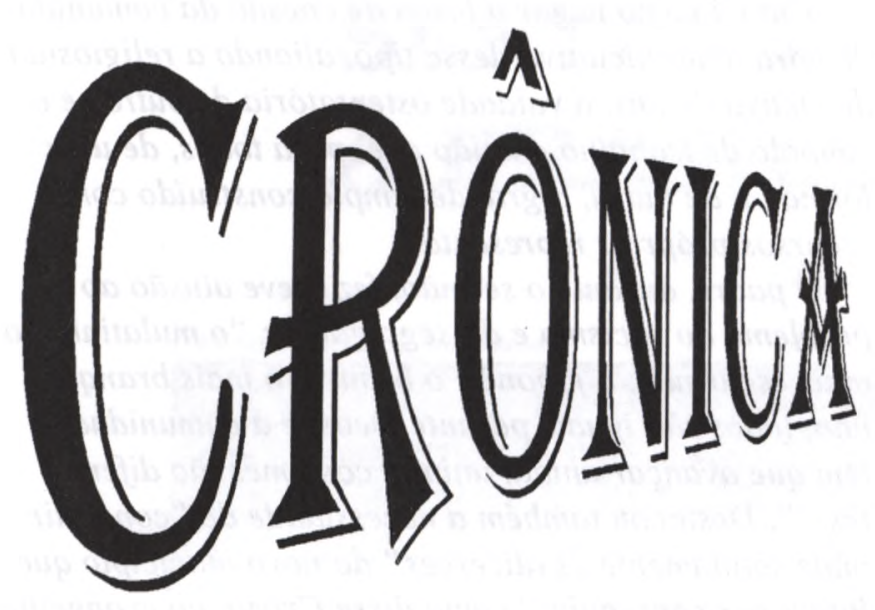

\title{
FESTA “GAƯCHA" NOS GERAIS DA BAHIA
}

\author{
Rogério Haesbaert *
}

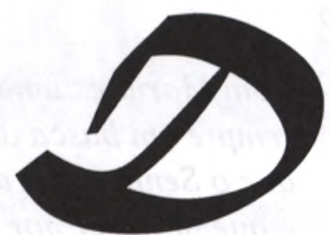

omingo ensolarado em Mimoso do Oeste, nos Gerais do oeste baiano. O movimento aumentava rapidamente. Chegavam carros último tipo, camione:es, caminhões (carregados de soja, inclusive). Outros, moradores próximos ou mais humildes, vinham a pé, mas a roupa era sempre l:m distintivo claro: domingueira e, mais do que isso, à altura de uma festa rara como aque'a, para a inauguração da primeira igreja da comunidade. ${ }^{.}$ Apesar de um tanto "fora do lugar", pois havia chegado à localidade no dia anterior, senti-me como que transladado no tempo, quando da minha primeira comunhão na igreja de Mata, cidadezinha de mil habitantes na serra de colonização ítalo-germânica no centro do Rio Grande do Sul. As mães carregando bolos e tortas para vender na festa, as meninas vestidas a rigor, todas de branco, vestido de renda, laço de fita no cabelo. E loiríssimas, como se tivessem sido escolhidas a dedo na sua pureza germânica para abrilhantarem a frente da procissão.

Estáticas à porta do vasto salão da Associação de Moradores, que também funcionava como clube, onde começaria o cortejo, mais pareciam um quadro de Renoir pintado de forma surrealista sobre o cálido e tropical cerrado baiano. Quando tirei os olhos daquela cena e deparei ao meu lado com três moleques negrinhos, mal vestidos e à vontade, soltando rojões, totalmente alheios ao formalismo daquelas estatuetas arianas, segurando seus cestinhos brancos à espera do toque de partida, deu vontade de gritar. Era contraste demais reviver toda aquela "tradição" num ambiente tão diverso, num tempo aparentemente tão distante, tradição que um dia fora tão "natural", tão "sagrada", e que agora me agredia fundo.

1- Este depoimento faz parte, como anexo, de tese de doutoramento defendida junto à USP em 1995, sob o título: "Gaúchos" no Nordeste: modernidade, des-territorialização e identidade. 
A ambiguidade, é claro, logo se faria presente: tenho laços ou no mínimo história, "raízes" comuns com essa gente, não adianta querer negar. Nunca soube bem o que é "ser gaúcho", é verdade, mas a sensação, paradoxal, muitas vezes, é a de que, mesmo sem defini-lo, nunca consegui deixar de sê-lo. Trocando o "nordestino" por "gaúcho", repito como minhas as palavras de Rachel de Queiroz que, indagada sobre sua condição de nordestina num programa de televisão ("Fantástico", Rede Globo, 12/06/1994), disse mais ou menos assim: "essa condição de ser nordestino é tão forte que a gente não sabe se é, não sabe se não é; tem que tomar cuidado para não ser tanto".

A procissão parte e, como que para contentar-me um pouco, num ecletismo "à brasileira", a imagem no alto é de Nossa Senhora Aparecida, a Maria afrobrasileira, um elo aparente com esta terra baiana. Mas quem a carrega são os gaúchos mais ilustres do lugar, "benfeitores" que conseguiram erguer a igreja, "talvez a mais bela da região", como disse o padre. Templo católico, aqui, como no Sul, é um importante símbolo de status para a comunidade.

Acompanhei a procissão ao largo, aproveitando para fotografar os fogueteiros que, sem fósforos, à última hora, apelaram para um baiano mais humilde que passava. Um dos principais mentores da festa, que é também um dos agricultores mais ricos da região, falou-me com um enorme sorriso, numa satisfação meio infantil, que "um dos quatro padres que trouxemos pra missa, italiano, vindo de Ibotirama, ficou encantado com o foguetório já um dia antes da festa, e disse 'mas hoje, tão soltando fogos? Isso realmente não é Nordeste!'” Que festança! Em todos os sentidos ela teria que ser a maior, a mais animada de toda a região, afinal de contas, estava sendo realizada, aos olhos de muitos, na primeira "comunidade sulista" da Bahia. E se a igreja não é a maior, é certamente uma das maiores de todo o oeste baiano.

Durante a missa foi muito aplaudida a comissão criada para a construção da igreja e foi contada sua história, desde a primeira missa no local, em 1983. O templo, em forma de um amplo leque, é de fato monumental. Discreto nas formas, ele se impõe pelo tamanho. Uma ampla estrutura metálica apóia o teto de zinco, lembrando um silo graneleiro. As janelas em forma de triângulo, mais de uma dúzia, exibem enormes vitrais. Apesar de já estarem prontas apenas as da parte frontal, o padre fez questão de ressaltar que as demais já haviam sido doadas, e que em breve seriam instala- das.

Não há como negar a força de coesão da comunidade para uma iniciativa desse tipo, aliando a religiosidade efetiva de uns, a vaidade ostentatória de outros e o símbolo de trabalho e união que, para todos, de uma forma ou de outra, o grande templo construído com recursos próprios representa.

$O$ padre, durante o sermão, fez breve alusão ao problema do racismo e da segregação: "o mulatinho, o mais escurinho, o japonês, o branco, o mais branquinho, todos são iguais perante Deus, e a comunidade tem que avançar unida, unindo costumes tão diferentes...". Destacou também a necessidade de "construir mais solidamente os alicerces" do novo município que lutam por conseguir: "como disse Cristo, no evangelho, precisamos primeiro construir as bases, sólidas, erguer nossa casa sobre a rocha, não sobre a areia" $e$ "em Mimoso ainda falta muita coisa: ruas calçadas, médicos, apesar de tudo que já se fez, ainda falta muito...".

Na igreja, durante a missa, apesar da nítida preponderância de sulistas classe média, o que reflete apenas em parte a real composição da população local, parecia ocorrer uma total irmandade com os baianos, em geral mais pobres, estabelecendo-se uma democracia quase sempre fictícia, onde todos cantavam juntos hinos como:

Com Maria estamos a caminho, sempre em busca da terra prometida que o Senhor deu ao povo com carinho e que deve ser por todos repartida.

$$
\text { ( ... ) }
$$

A pobreza invadiu a humanidade nossa gente morre aos poucos, sem alento. Falta pão, amor e paz neste momento, ó Maria vem nos dar fraternidade.

Sim, ó Pai, te bendizemos pois os justos vão vencer, os pequenos e humildes em teu reino vão viver.

Sim, ó Pai te bendizemos os humildes exaltais, os soberbos e orgulhosos de seus tronos derrubais.

Um momento puramente simbólico de igualdade e denúncia de injustiças sociais que, com os cânticos $e$ orações inflamadas, participativas, chegava a emocio- 
nar. Permaneci numa das laterais da igreja, junto a uma das janelas abertas, olhando ora a multidão multicolor no interior do templo, ora a incrível imensidão dos cerrados, disposta na imensa planura da chapada, com uma ou outra casa e velhas árvores retorcidas, sobreviventes da devastação agrícola ao redor. Mesmo com todos os visitantes de Barreiras, amigos sulistas que vieram para a festa, a igreja não lotou. Imagino em outros dias, o vazio deste prédio imenso, capaz de abrigar provavelmente duas vezes a população atual da localidade. Certamente o prédio foi projetado prevendo, num futuro não muito distante, $o$ crescimento que Mimoso promete apresentar.

No churrasco e no jogo de bocha que se sucederam à missa, o domínio dos sulistas era total. Não só por serem hábitos alheios à gente da terra, mas também pelo preço ( $C r \$ 2.500,00$, uns US\$ 6,00 o espeto) o que excluía os mais pobres, representados basicamente pelos baianos. Não é à toa que a "periferia" ou "o outro lado" de Mimoso (loteamento à margem sul da rodovia asfaltada que corta a localidade) é ocupado pelos "outros", os baianos pobres, vindos de Irecê, Xique-Xique, Pilão Arcado.

Acabei almoçando com uma família de Bela Vista, uma localidade que havia visitado há alguns meses próxima à divisa com Tocantins, numa das áreas mais férteis dos cerrados. Pequenos agricultores no planalto gaúcho, eles migraram para a região em busca de terras, e acabaram conseguindo comprar cerca de 50 hectares, o que é considerado muito pouco nos Gerais. Na ocasião eles afirmavam que sua casa no pequeno vilarejo ficava sobre a "linha divisória" entre a área habitada pelos descendentes de italianos e a habitada pelos descendentes de alemães, que só se reuniam pra valer nas festas da capela e nos jogos de bocha, demonstrando a complexidade dos recortes no interior da pretensamente monolítica "identidade gaúcha".

As competições esportivas, logo vi, geralmente associadas às festas religiosas e aos "fandangos" (bailes "à gaúcha"), representavam ao mesmo tempo um momento de congraçamento e uma ocasião para cada "comunidade" sulista dos Gerais mostrar a sua força. Assim, durante o almoço foi grande a discussão sobre "os melhores" de Mimoso, Novo Paraná, Bela Vista, Placas, como se já começassem a se delinear ali as primeiras identidades com esses novos territórios de âmbito local.

À tarde percorri cerca de dois quilômetros a pé, em um loteamento deserto ainda tomado pelo cerrado, até encontrar a área habitada pelos migrantes do sertão nordestino, casas autoconstruídas ou barracos rudimentares, improvisados, em terras de, antiga fazenda do "coronel Aroldo", doadas para os primeiros moradores. Dona Maria das Dores, uma das primeiras a chegar, há três anos, já havia cedido uma parte de seu terreninho ("que não dá nem pr'uma roça") para outra migrante, jovem com cinco filhos. Seu marido, segundo ela, "ganha uma ninharia" num emprego que conseguiu na CEVAL, que à época estava construindo sua fábrica de óleos vegetais, a maior da Bahia. Não há luz elétrica, a escolinha, improvisada na igreja "dos crentes", é particular, e a água vem de um poço rústico, com 17 metros de profundidade.

Enquanto do outro lado o templo católico é ponto de convergência e representa de certa forma, juntamente com o salão da Associação de Moradores (onde até então se realizavam as missas), o centro articulador da vida social comunitária, a maloca ou periferia pobre de Mimoso já nasce com sua "igreja dos crentes", primeiro ponto de reunião e da coesão social ainda incipiente entre os moradores. Ficou nítida, ali, a função aglutinadora do templo pentecostal na organização do espaço comunitário do migrante nordestino, tanto quanto o templo católico (e suas festas onde é revivido $o$ "tradicionalismo" gaúcho) o é para os migrantes sulistas.

Como disse-nos uma migrante de Pilão Arcado, que havia chegado há um ano, "a fama desse Mimoso corre a Bahia toda, moço". Desse jeito, dá pra imaginar o que será a cidade daqui a uns 20 anos - mais um retrato das violentas contradições, "insolúveis", desse imenso e tão rico país. Nestes primeiros anos, contudo, as iniciativas pela emancipação e a resistência, nem sempre explícita, da elite política baiana revelam bem que Mimoso ainda é vista como uma "comunidade gaúcha" nos Gerais baianos.

A esperança, remetendo-nos para um futuro de terceiras e quartas gerações de sulistas, é que festas de igreja como a que aqui relatamos sirvam não apenas para reforçar os símbolos da identidade/diferença sulista, mas sejam uma prática efetivamente integradora entre "gaúchos" e baianos, pela construção de novos traços identitários, mais híbridos, onde cada grupo saiba dialogar com seus valores, em busca da difícil integração entre duas culturas tão distintas mas que ocupam hoje espaços geográficos comuns dentro da enorme diversidade sócio-territorial brasileira.

* Rogério Haesbaert é Prof. do Dpto. de Geografia da UFF-Niterói. 